\title{
Effect of feeding sweet orange peels on bloodglucose and lipid profile in Diabetic and hypercholesterolemic rats
}

\author{
Elsayed M Hammad; Magda R Kostandy and Doaa H El-Sabakhawi
}

National Nutrition Institute, Cairo Egypt

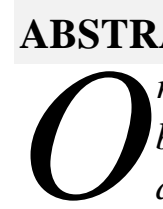

beneficial to our health. Presentstudy aimed to investigate the effects of

different doses of orange peels on blood glucose, lipid profile and some physiological parameters as liver and kidney functions in diabetic and hypercholesterolemic rats. Rats were divided into 3 main groups, first main group negative control, second main group diabetic rats and third main group hypercholesterolemia. Second and third main groups were divided into four sub-groups (six rats / group) and fed with different diet levels of orange peels (5\%, $7.5 \%$, and 10\%) for 28 days. Bodyweight gain, feed intake, feed efficiency ratio and relative weight of some organs were calculated at the end of experiment. Fasting blood sample were taken for determination of serum glucose, total cholesterol, triglycerides, creatinine, urea, aspartate aminotransferase (AST) and alanine aminotransferase (ALT). There was a significant reduction in both serum total cholesteroland Triglycerides in all treated groups with orange peels. The higher peels doses improved liver and kidney functions. However, the highest reduction was achieved by feeding diabetic rats with $10 \%$ orange peels. Study concluded orange peels ameliorated blood glucose, lipid profile and liver, kidney function.

Key words: - orange peel, blood glucose, lipid profile, liver and kidney functions 
Effect of feeding sweet orange peels on blood glucose and lipid profile in Diabetic and hypercholesterolemic rats

Elsayed M Hammad; Magda R Kostandy and DoaaHEl-Sabakhawi

\section{INTRODUCTION}

Oranges are widely grown in warm climates worldwide, and the flavors of oranges vary from sweet to sour. The fruit is commonly peeled and eaten fresh, or squeezed for its juice (Bender and Bender. 2005).

However orange peels contain compounds that are beneficial to our health. The peel of one medium orange contains over 60 flavonoids and 170 different phytonutrients (Myers, 2011).

Flavonoids that consist mainly ofterpenoidssuch as limonene,linalool and other volatile oils are the major ingredients of orange peels. Pectin is the type of carbohydrate in orange peels. Orange peels provide $139 \mathrm{mg}$ of vitamin $\mathrm{C}$ per100g. It also provides vitamin $\mathrm{A}$ and Bcomplex and minerals such as calcium, selenium, manganese and zinc Morton, (1987).

Diabetes mellitus, is one of the most common metabolic disorders has caused significant morbidity and mortality (Patel et al., 2012). WHO (2017)defined diabetes is a chronic disease that occurs either when the pancreas does not produce enough insulin or when the body cannot effectively use the insulin it produces. Insulin is a hormone that regulates blood sugar. Raised blood sugar is a common effect of uncontrolled diabetes and over time leads to serious damage to many of the body's systems, especially the nerves and blood vessels.

Since 1932, diabetes mellitus has been among the top 10 leading causes of death in America. It is a major cause of blindness, renal failure, congenital malformation, and lower extremity amputation (ADA 2014). Hyperlipidemia and hypercholesterolemia are important risk factors for the development of atherosclerosis and coronary artery disease (Gielen et al 2009).

The main pathogenic bloodparameters are increased concentrations of cholesterol bound to low-density lipoprotein (LDL-C), total cholesterol (T. Chol) and triglycerides (TG)(Jones, 2008). Majority of therapeutic protocols rely on drugs that belong to statin 
Effect of feeding sweet orange peels on blood glucose and lipid profile in Diabetic and hypercholesterolemic rats

Elsayed M Hammad; Magda R Kostandy and DoaaHEl-Sabakhawi

family. Statins inhibit the activity of 3-hydroxy-3methylglutaryl-CoA (HMG$\mathrm{CoA}$ ) reductase, which catalyzes the rate-limiting step in mevalonate biosynthesis, a key intermediate in cholesterol metabolism.

This is associated with a decrease in T. Chol and a switch from LDL-C to high-density lipoprotein (HDL-C) fraction. Despite the significant clinical benefits provided by statins many patients, in particular those with metabolic syndrome, do not achieve the recommended low-density and High-density lipoprotein (LDL, HDL) cholesterol target goals with statins (Jones 2008). Moreover, the use of statins is forbidden in more than $40 \%$ of patients eligible for this therapeutic approach, mostly for the occurrence of side effects including muscle pain (myalgia), muscle weakness (myopathy) or liver diseases in more severe cases (Alsheikh-Ali and Karas2009), Joy and Hegele (2009) whoreported limits the use of statins and suggests the need of other alternative therapy.
Wolf, (2010)reported that orange peels are a source of health-promoting carbohydrates. Peels also contain healthy polymethoxylatedflavones (PMF), which are plant pigment compounds, present in all citrus fruits.

Several authors found that the PMF compounds in citrus peels have the potential to lower cholesterol when included in diet as well as LDL cholesterol without the side effects of mainstream cholesterol drugs. Orange peel and pulp contain hesperidin, a flavonoid that helps to lower cholesterol and triglycerides. Orange peel being rich in pectin which is a natural fiber helps to reduce cholesterol levels (Youssef, et al.2013)

\section{AIM OF THE STUDY}

This study aimed to evaluate the effect of sweet orange peels on blood glucose level, lipids profile and some physiological parameters as liver and kidney functions in diabetic and Hypercholesterolemic rats. 
Effect of feeding sweet orange peels on blood glucose and lipid profile in Diabetic and hypercholesterolemic rats

Elsayed M Hammad; Magda R Kostandy and DoaaHEl-Sabakhawi

MATERIALS \& METHOD:

Materials:

Orange peels (Citrus sinensisL):- orange peels were obtained from local market. Orange peels were cleaned from impurities and washed with tap water. For drying, air dryer oven at $\left(45^{\circ} \mathrm{C}\right)$ was used for 48 hours, and thenpeels were ground in aMulti Mill apparatus and passed through a $0.5-\mathrm{mm}$ mesh sieve to obtain a fine peel powder.

Rats: - fifty four healthy adult male albino rats "Sprague Dawley strain" whose weight between 200-210 g were obtained from research institute of ophthalmology medical analysis department, Giza, Egypt. The animals kept in single wire cages with wire bottoms under hygienic conditions and controlled laboratory conditions of temperature $\left(25^{\circ} \mathrm{C}\right)$, lighting and ventilation. Food and tap water were provided ad-libitum and checked daily. .

Diet:The standard diet prepared as described by Reeves et al.
(1993), (AIN1993). The vitamins mixture and salt mixture were prepared according to $(\mathrm{AIN}, 1977)$.

\section{Experimental design:}

Adult male albino rats fed on standard diet for one week for adaptation then, they were divided into three groups $(n=18)$. The first group (A) fed on standard diet only and served as control group.Secondgroup (B): (diabetic groups). Diabetes was induced in normal healthy adult male rats by injection of alloxan $150 \mathrm{mg} / \mathrm{kg}$ body weight according to the method described

by

\section{DesaiandBhide,(1985).}

Sixhours after the injection of alloxan, fasting blood samples were obtained by retro-orbital method to estimate fasting serum glucose. Rats having fasting serum glucose more than $200 \mathrm{mg} / \mathrm{dl}$ were considered diabetics (NDDG, 1994). Then was divided to subgroups as the following: Subgroups Control B: Fed on basal diet as the positive diabetic control. Subgroups B1, B2 and B3 were fed on basal diet $+5 \%, 7.5 \%$ and 
Effect of feeding sweet orange peels on blood glucose and lipid profile in Diabetic and hypercholesterolemic rats

Elsayed M Hammad; Magda R Kostandy and DoaaHEl-Sabakhawi

$10 \%$ orange peel respectively replaced equal amount of starch.

Third group

(C)(hypercholesterolemic groups):Hypercholesterolemia was induced in normal healthy adult male albino rats by feeding on hyperlipidemia diet (1.5\% cholesterol and $+10 \%$ lard) for 2 weeks, then fasting blood sample was obtained to estimateserum total cholesterol and TG level. When insure rats have hypercholesterolemia then divided into subgroups as the following: Subgroups Control C: Hypercholesterolemia as a positive control fed on basal diet;Subgroups C1, C2 and C3 were fed on basal diet $+5 \%$, $7.5 \%$ and $10 \%$ orange peel respectively replaced equal amount of starch for 28 days.

At the end of the experiment period, the animals were sacrificed after being fasted (overnight)under anesthetized and blood samples collected in dry centrifuge tubes from hepatic portal vein. The organs (liver, kidney, and spleen) of each animal was quickly removed by careful dissection, washed in saline solution
(0.9\%), dried using filter paper then rapidly weighed separately to calculate the absolute and relative organs weight. Serum separated by centrifugation of blood at $4000 \mathrm{rpm}$ (round per minute) for 15 minutes at room temperature and kept in plastic vial at $-20^{\circ} \mathrm{c}$ till analysis.

Methods:

Chemical analysis of peels:-

Crude protein, fiber, fat, and ash content were determined following the method described by (AOAC, 1995).

\section{Biochemical parameters:}

Enzymatic colorimetric method used to determineserum glucose according to Kaplan (1984).Determination of serum Cholesterol was made according to (Allain et al., 1974). Enzymatic determination of triglycerides in serum was conducted according to(Fossati and Prancipe, 1982). Creatinine was determined according to the method described by (Bohmer 1971). Urea was determined according to the method described by(Patton and Crouch 1977).(AST) and 
Effect of feeding sweet orange peels on blood glucose and lipid profile in Diabetic and hypercholesterolemic rats

Elsayed M Hammad; Magda R Kostandy and DoaaHEl-Sabakhawi

(ALT)activities were measured according to the method described by(Reitman and Frankel 1957).

\section{Statistical analysis:}

The data were expressed as means \pm standard deviation (mean $\pm \mathrm{SD}$ ). All variables were tested for normal distribution using one way analysis of variance (ANOVA) $(\mathrm{P}<0.05)$. If the groups showed significant differences, Turkey's multiple comparison tests was performed with Snedecor and Cochran (1972). Statistical analysis was carried out using the program of Statistical Package for the Social Sciences (SPSS), PC statistical software (Version 16; UntitledSPSS Data Editor).

\section{RESULTS \& DISCUSSION}

Data in table indicated that fiber was 9.33 $\mathrm{g} / 100 \mathrm{~g}$ dried orange peels represents approximately onethird of the recommended daily intake. Dietary fiber that is fundamental and intact in fiber-rich foods (eg, fruits, vegetables, legumes, whole grains) is widely recognized to have beneficial effects on health when consumed at recommended levels $(25 \mathrm{~g} / \mathrm{d}$ for adult women, $38 \mathrm{~g} / \mathrm{d}$ for adult men)(McRorie 2015).

Johansson et al., (2014) concluded that high dietary fiber intake help to prevent the risk of cardiovascular disease.

Data in table 2 showed that, the mean values of feed intake of diabetic group fed on basal diet and treated with orange peels $(\mathrm{B} 1, \mathrm{~B} 2, \mathrm{~B} 3)$ ranged between $10.65 \pm 0.28$, $9.65 \pm 0.28$ and $8.67 \pm 0.03$ g/day. The values of feed intake of diabetic rats that treated with diets containing different doses of orange peels weredecreased significantly than that fed on Basel diet (negative control). Data also showed that, the mean values of feed intake of hypercholesterolemia group fed on basal diet and treated with orange peels ranged between 12.21 to $13.93 \mathrm{~g} /$ day. It could be noted that the differences in values of feed intake among all treated groups were not considerable 
Effect of feeding sweet orange peels on blood glucose and lipid profile in Diabetic and hypercholesterolemic rats

Elsayed M Hammad; Magda R Kostandy and DoaaHEl-Sabakhawi

compared with the positive control group,as the obtained data showed a slight variation in feed intake between treated groups. These results are in accordance with those reported by Wiley and Sons (2008)who said that the variation in feed intake between treatments may be due to the active components of the added materials.

Feeding rats on basal diet containing orange peel $\mathrm{B} 1$ and B3 resulted in non-significant changing in FER as compared to positive control group (B).Although the mean values of feed intake were almost the same, feed efficiency ratio showed anon-significant increase compared with the negative control group. This may be due to the increase of body weight during the experimental period as a result of highly utilization of the added materials and its positive effect. The obtained data in table (2) also revealed that feeding hypercholestrolemia rats on basal diet containing orange peels $\mathrm{C} 1, \mathrm{C} 2$ and $\mathrm{C} 3$ treatments showed a highly significant positive correlation vis FER and BWG while a non-significant negative correlation was found vis FI.The obtained results were inagreement with those reported by youssef, et al. (2013) who indicated that when the treatments increased in its amounts (to a limit value), FER and BWG increased.

Table 3 illustrated that in diabetic rats a gradual increase in relative organs weight when the doses of orange peels increased. The statistical analysis showed a highly significant positive correlation between treatments and organs ratio.This may be due to good antioxidant action of orange peels against the free radicals. These results are in accordance with those of oluremi et al. (2008);Wiley and Sons (2008) who found that there was increase in kidney/body weight ratio. Theobtained data fromhypercholestrolemic ratsfedon basal diet containing orange peels by groups $\mathrm{C} 1, \mathrm{C} 2$ and $\mathrm{C} 3$ asignificant negative correlation was found concerning spleen while other 
Effect of feeding sweet orange peels on blood glucose and lipid profile in Diabetic and hypercholesterolemic rats

Elsayed M Hammad; Magda R Kostandy and DoaaHEl-Sabakhawi

organs showed non-significant correlation. This means that the treatments affected spleenwith no effect on other organs. These results were in agreement with those reported byHossin et al. (2009) Moreover, It suggested that, consumption of peel powder or its extract may modify the risk of hypercholesterolemia and it have more potential as a health supplement rich in natural antioxidants.

Table 4 observed that blood glucose showed gradual decrease in diabetic rats after 4 weeks (as an experimental period) with the increase of supplement dose. These results are in agreement with those reported by Youssef $\boldsymbol{e t} \boldsymbol{a l}$. (2013) who reported that, peels marked protection, it brought down the level of blood sugar.Chifai et al. (2003) who suggested that, glucose lowering effects are most often associated with viscous fiber that lies in the soluble dietary fiber content of peels. Also these results were in accordance with Spandana, et al (2016) who found that orange peels and orange peel extract can provide benefits to diabetic patients and may reduce overeating. This is due to the natural fiber in orange peels as a natural source of pectin which helps in reducing blood sugar.

Serum total cholesterol and Serum triglycerides in diabetic rats fed different doses of orange peel in table (5) showed a gradual decrease as the level of supplement increased. Data of hypercholestrolemic rats feeding on basal diet containing orange peels also showed that, total cholesterol andtriglycerides levels $(\mathrm{mg} / \mathrm{dl})$ were increased significantly $(\mathrm{P}<0.05)$ for rats fed on hypercholesterolemia diet (group C), compared to (group A) the negative control (206.55 \pm 12.38 and $120.7 \pm 3.11$ ) vs. $\quad(78.39 \pm 0.78 \quad$ and 97.68 \pm 1.76 ).Total cholesterol and triglycerides of groups $\mathrm{C} 1$ and $\mathrm{C} 2$ decreased significantly $\quad(\mathrm{P}<0.05) \quad$ when compared with group (C).The statistical analysis showed a significant decreasein total cholesterol and triglycerides of all treated groups with different 
Effect of feeding sweet orange peels on blood glucose and lipid profile in Diabetic and hypercholesterolemic rats

Elsayed M Hammad; Magda R Kostandy and DoaaHEl-Sabakhawi

doses of nutritional peels when compared with control positive group. On the other hand, it showed a negative correlation between total cholesterol, triglycerides and doses of nutritional peel as seen in group C3 but still lower than positive control, this may be due to the increase of food intake.The study denotes that treatments under the study reduced serum cholesterol and triglycerides concentration and the highest reduction was achieved by feeding hypercholesterolemic rats on $\mathrm{C} 2$.This present results were in the same line with that reported by Youssef $\boldsymbol{e t} \boldsymbol{a l}$. (2013) who saidthat fortified biscuits with citrus peels powders reduced the levels of serum cholesterol, triglycerides and LDL cholesterol, both of which are known to contribute to disorders such as diabetes, obesity and increase risks of heart disease. The polymethoxylated flavones (PMF) in orange peels have cholesterol-lowering properties. Meanwhile, fortified biscuits with citrus peels powders raised HDL cholesterol level, which is beneficial because it can counteract the high level of the bad cholesterol (LDL cholesterol) than some prescription drugs without the risk of side effects. Orange's peels may be more effective at lowering cholesterol than other citrus fruits because they contain PMFs and another flavonoid, hesperidin, which also help to lower cholesterol. Fortified biscuits with $10 \%$ Abo-Sora orange peels powders are recommended for caloric reduced diet for obese, overweight and diabetic persons. Also these results are in acceptance with Wiley and Sons (2008) who revealed thatcitrus sinensis peels decreased the concentration of different serum lipids such as total cholesterol (TC), triglycerides (TG), lowdensity lipoprotein cholesterol (LDL-C) and very low-density lipoprotein cholesterol (VLDLC).Also, results were in agreement with kelawala and Ananthanaryan (2004),Seham et al. (2011), who reported that orange peels had more favorable effects on blood lipids and plasma lipoproteins as well as on 
Effect of feeding sweet orange peels on blood glucose and lipid profile in Diabetic and hypercholesterolemic rats

Elsayed M Hammad; Magda R Kostandy and DoaaHEl-Sabakhawi

the number and lipid content of LDL-c subtractions.

Table (6) shows the gradual decrease of (AST) levels with the increase in the supplement dose. ALT levels decreased gradually when the supplement dose increased.In both diabetic rats control (B) and hypercholesterolemia rats control (C) showed highlysignificant increase in both AST and ALT enzyme levels compared with the healthy rats control (A).Data in the same table showed that serum AST andALT levels were decreased significantly $(\mathrm{p}<0.05)$ in all treated groups compared with the control (B) and (C).These results may be attributed to the fact that orange peels are rich in polyphenols which exhibit antioxidant and antiinflammatory act capacities in vitro. The obtained results were in agreement with those of Abdel-Rahim, et al.(2013) who found that fruit peels did not cause any adverse effect on AST and ALT. but these results did not match with a study byOchukoet al. (2012)who mentioned that higher AST and lower ALT activities were observed in orange peel oil fed groups.

Table (7) indicated thatcreatinine and urea levels in both diabetic control group (B) and hypercholesterolemic control group $(\mathrm{C})$ increased compared with the healthy control group (A). A gradual decrease of serum creatinine and Urea were observed, as the feeding dose of orange peel increased.These results were in the same line withParkar and Addepalli(2014) who found that using of orange peel extract improved renal functions and significantly prevented the increase in creatinine, urea and blood urea nitrogen levels.Also the effect of orange peels in the present study is similar to those described bySpandana, et al (2016) who mentioned that serum urea and creatinine levels were reduced due to the active components in orange peels.

\section{CONCLUSION:}

Study concluded that orange peels as a rich source of 
Effect of feeding sweet orange peels on blood glucose and lipid profile in Diabetic and hypercholesterolemic rats

Elsayed M Hammad; Magda R Kostandy and DoaaHEl-Sabakhawi

fiber that is intrinsic and intact in whole foods and antioxidant as active components. Study observed a significant reduction in blood glucose level, hypercholesterolemic and liver, kidney function after intake high dose $(10 \mathrm{~g})$ from orange peels in diabetic and hypercholesterolemicrats.

\section{REFERENCES}

Abdel-Rahim, E. A.; ElBeltagi, H. S. andRomela, R. M, (2013):

White bean seeds and Pomegranate peel and fruit seeds as ‘hypercholesterolemic and hypolipidemic agents in albino rats,GrasasyAceites (Sevilla). 64(1):50-58. many ref.

\section{ADA (2014), American} Diabetes Association:

Diagnosis and
classification
diabetes
mellitus.Diabetes
37 (1) 81 - 90.

ADA (2001), American Diabetes Association:

Screening for diabetes.Diabetes care 24 (supply :521-524

AIN(1977):

American Institute of Nutrition (AIN), Committee on Standard Nutritional Studies. J. Nutr. 107:1340-1348.

\section{AIN (1993):}

American Institute of Nutrition (AIN), Purified diet for Laboratory Rodent.J. Nutr.123:19391951.
Allain, C. Z.; Poon, L. S. and Chan, C. S. (1974):
Enzymatic determination of total serum cholesterol.Clin.Chem., 20:470 - 475 .
Alsheikh-Ali, A.A. and Karas, R.H. (2009):
The relationship of statins to rhabdomyolysis, malignancy, and hepatic toxicity: evidence from clinical trials. 
CurrAtheroscler Rep.,

11: 100-104.

A.O.A.C (1995):

Official Methods of Analysis, Association of Official Analytical Chemists. $16^{\text {th }} \quad$ Ed., Washington D.C.

Bender DA and Bender AE (2005):

A Dictionary of Food and Nutrition. New York: Oxford University Press. ISBN 0198609612

Bohmer, H. B. U. M. (1971):

Micro-determination of creatinine.Clin.

Chem.Acta, 32: 81 85.

Chifai C; Huang, Y. and Lee, M.(2003):

In vitro hypoglycemic effects of different insoluble fiber-rich fractions prepared from the peel of Citrus sinensis L. cv. Liucheng. Journal of Agricultural and Food Chemistry. 51(22):6623-6626.
Desia, A. and Bhide, M. (1985):

Hypoglycemic effect of hanitioniasuaveolens.Indi an. J. Med. 81: 86-91.

Falholt, K.; Lund, B. and Falholt, W. (1973):

Clin.Chem. Acta, 49,105.

Fassati, P. and Principe, L. (1982):

Enzymatic colorimetric method for the determination of triglycerides, J.Clin. Chem., (28):2077

Gielen, S.; Sandri, M.; Schuler, G. and Teupser, D. (2009):

Risk factor management: antiatherogenic therapies. Eur. J. Cardiovasc Prev.Rehabil., 16(Suppl. 2): S29-36.

Hossin, F. L. A. (2009):

Effect of pomegranate (Punicagranatum) peels an it's extract on obese hypercholesterolemic rats . Pakistan Journal of 
Effect of feeding sweet orange peels on blood glucose and lipid profile in Diabetic and hypercholesterolemic rats

Elsayed M Hammad; Magda R Kostandy and DoaaHEl-Sabakhawi

Nutrition;(8):1251-1257.

34 ref.

Ann. Intern. Med., 150(12): 858 - 868.

Johansson-

\section{PerssonA ; UlmiuslM; Cloeten}

s L; Karhu T; Herzig KH and Önning G (2014):

A high intake of dietary fiber influences Creactive protein and fibrinogen, but not glucose and lipid metabolism, in mildly hypercholesterolemic subjects, European Journal of

Nutrition Volume

53, Issue 1, pp 39-4

Jones, P.H. (2008):

Expert perspective: reducing cardiovascular risk in metabolic syndrome and Type 2diabetes mellitus beyond lowdensity lipoprotein cholesterol lowering. Am.J.Cardiol.,102:41L-47 $\mathrm{L}$.

Joy, T.R. and Hegele, R.A. (2009):

Narrative review:

Statinrelated myopathy.
Kaplan, A. (1984):

Determination of blood glucose.Cline.chem. The C.V. Mosby.Co. St Louis Toronto. Princeton, pp. 1032 - 1036.

Kelawala, N. S. and Ananthanarayan L. (2004):

Antioxidant activity of selected foodstuffs, InternationalJournal of Food Sciences \& Nutrition 55(6):511-516, Paper. ISSN 0963-7486.

McRorieJW. (2015):

Evidence-Based

Approach to Fiber

Supplements and

Clinically Meaningful Health Benefits, Part 1, Nutr Today. 50(2): 8289.

\section{Morton, J. (1987)b:}

Orange. p. 134-142. In: Fruits of warm climates. Julia F. Morton, Miami, FL 
Effect of feeding sweet orange peels on blood glucose and lipid profile in Diabetic and hypercholesterolemic rats

Elsayed M Hammad; Magda R Kostandy and DoaaHEl-Sabakhawi

Myers, C. (2011):

A list of the benefits of orange peels

http://www.livestrong,co

m/article/440499-a-list-

of-the-benefits-of-

orange-peels/ ixzz21

fucox HV.

Najafzadeh, H.; Aghel, N.; Hemmati, A. A. and Oulapour, S.,(2010):

Effect of hydro alcoholic extract of peel of Punicagranatum on experimental diabetes mellitus by streptozotocin in rats.Pharmaceutical

Sciences; 2010. 16(4):239-248.

NDDG(1994), National Diabetes Data Group:

Classification and diagnosis of diabetes mellitus and other categories of glucose intolerance.Diabetes, 28:1039-1057.

Ochuko L. Erukainure, John A. Ajiboye; Florence F.
Davis;KemisolaObabire.and Muhammad Aliyu (2012): Effect of Orange (Citrus sinensis) Peel Oil on Lipid Peroxidation, Catalase activity and Hepatic Biomarker levels in Blood Plasma of Normo Rats 1Journal of Biomedical and PharmaceuticalResearch 1(1),16-23.

Oluremi, O. I. A.; Mou, P. M. and Adenkola, A. Y. (2008):

Effect of fermentation of sweet orange (Citrus sinensis) fruit peel on its maize replacement value in broiler diet.Livestock Research for Rural Development. 20(2):20020. 19 ref.

Parkar N, Addepalli V (2014):Amelioration of diabetic nephropathy by orange peel extract in rats. Nat Prod Res 28(23): 217881 
Effect of feeding sweet orange peels on blood glucose and lipid profile in Diabetic and hypercholesterolemic rats

Elsayed M Hammad; Magda R Kostandy and DoaaHEl-Sabakhawi

Patel DK, Prasad SK, Kumar $R$ and HemalathaS (2012):

An overview on antidiabetic medicinal plants having insulin mimetic property.Asian Pac J Trop Biomed, 320330.

Patton, C. and Crouch, S. R.(1977):

Determination of urea.Anal. Chem. 149:464-469.

Reitman, S. and Frankel, S.(1957):

A color metric method for the determination of serum glutamic oxaloacetic and glutamic pyruvic

transaminases.Am. J. Clin. Path, 28: 56-63.

Seham, S. K.; Maha, H. M.; Madiha, M. A. K. and ElShobaki, F. A, (2011):

Evaluation of the health value of some beverages prepared from vegetable and fruit wastes.The Journal of
American Science; 7(9):328339. 43 ref.

Snedecor, G. W. and Cochran, W. G. (1972):

Statistical methods $6^{\text {th }}$ Ed.The Iowa State University Press. Ames. IA.

Spandana U., Sreedvi A, Havilah Esther.S and Lakshmalah (2016):

Effect of hespertin isolated from orange peels on cisplatinindused nephrotoxicity. Int J Pharm Bio Sci 2016 Oct ; 7(4): (P) 15 - 21

Trinder, P. (1969):

Determination of blood glucose.Ann.Clin.

Biochem.6: 24 - 33.

Wiley J and Sons, (2008):

Antiperoxidative, atithyroidal, antihyperglycemic and cardioprotective role of Citrus sinensis peel extract in male mice.School of Life Sciences, D. A. 
Effect of feeding sweet orange peels on blood glucose and lipid profile in Diabetic and hypercholesterolemic rats

Elsayed M Hammad; Magda R Kostandy and DoaaHEl-Sabakhawi

University, Takshashila

Campus, Indore 452017, India.

Youssef, M. K. E.; Youssef, H. M. K. E.; and Mousa, R. M. A,(2013):

Wolf, W. (2010):

Evaluation

of

Health properties of orange

antihyperglycaemic

peel

http://www.livestrong.

activity of citrus peels

powders fortified biscuits

com/article/346101-health-

in Albino induced

propertiesof-orange-

diabetic rats. Food and

peel/\#ixzz21 fqq8y MR.

Public Health.3(3):161167. 
Table (1): Chemical composition of dried orange peels ( $\mathrm{g} / 100 \mathrm{gm})$

\begin{tabular}{|c|c|c|c|c|c|c|}
\hline $\begin{array}{l}\text { Constituents } \\
\text { Material }\end{array}$ & $\begin{array}{c}\text { Protein } \\
\text { (g) }\end{array}$ & $\begin{array}{l}\text { Fat } \\
(\mathrm{g})\end{array}$ & $\begin{array}{c}\text { Fiber } \\
(\mathrm{g})\end{array}$ & $\begin{array}{l}\text { Ash } \\
(\mathrm{g})\end{array}$ & $\begin{array}{l}\text { T. Carb. } \\
(\mathrm{g})\end{array}$ & $\begin{array}{c}\text { Total } \\
(\mathrm{g})\end{array}$ \\
\hline Orange peels & 1.41 & 2.1 & 9.33 & 6.78 & 80.38 & 100 \\
\hline
\end{tabular}

Table (2): Effect of feeding different doses of orange peels onfeed intake (FI), feed efficiency ratio (FER) and Body weight gain (BWG) in diabetic and hypercholesterolemicrats (Mean \pm SD)

\begin{tabular}{|c|c|c|c|c|c|c|c|c|c|}
\hline $\begin{array}{l}\text { Groups } \\
\text { Parameter }\end{array}$ & $\begin{array}{c}\text { A } \\
(-v e)\end{array}$ & $\begin{array}{c}\text { B } \\
(+v e)\end{array}$ & $\begin{array}{l}\text { B1 } \\
5 \%\end{array}$ & $\begin{array}{c}\text { B2 } \\
7.5 \%\end{array}$ & $\begin{array}{c}\text { B3 } \\
10 \%\end{array}$ & $\begin{array}{c}\mathrm{C} \\
(+\mathrm{ve})\end{array}$ & $\begin{array}{l}\mathrm{C} 1 \\
5 \%\end{array}$ & $\begin{array}{c}\mathrm{C} 2 \\
7.5 \%\end{array}$ & $\begin{array}{c}\mathrm{C} 3 \\
10 \%\end{array}$ \\
\hline $\begin{array}{l}\text { FI } \\
\text { g / day }\end{array}$ & $\begin{array}{c}14.32 \\
\pm \\
0.38 \\
\text { a }\end{array}$ & $\begin{array}{c}9.67 \\
\pm \\
0.03 \\
\text { ab }\end{array}$ & $\begin{array}{c}10.65 \\
\pm \\
0.28 \\
\mathrm{ab}\end{array}$ & $\begin{array}{c}9.65 \\
\pm \\
0.28 \\
\mathrm{ab}\end{array}$ & $\begin{array}{c}8.67 \\
\pm \\
0.03 \\
\text { ab }\end{array}$ & $\begin{array}{c}12.2 \\
\pm \\
0.35 \\
\text { ab }\end{array}$ & $\begin{array}{c}12.68 \\
\pm \\
0.35 \\
\mathrm{~b}\end{array}$ & $\begin{array}{c}13.14 \\
\pm \\
0.03 \\
\text { ab }\end{array}$ & $\begin{array}{c}13.93 \\
\pm \\
0.28 \\
\text { ab }\end{array}$ \\
\hline FER & $\begin{array}{c}0.105 \\
\pm \\
0.01^{\mathrm{a}}\end{array}$ & $\begin{array}{c}0.108 \\
\pm \\
0.09^{\mathrm{a}}\end{array}$ & $\begin{array}{c}0.11 \\
\pm \\
0.02^{\mathrm{b}}\end{array}$ & $\begin{array}{c}0.119 \\
\pm \\
0.02^{b}\end{array}$ & $\begin{array}{c}0.12 \\
\pm \\
0.09^{a}\end{array}$ & $\begin{array}{c}0.14 \\
\pm \\
0.02^{\mathrm{g}}\end{array}$ & $\begin{array}{c}0.118 \\
\pm \\
0.01^{\mathrm{g}}\end{array}$ & $\begin{array}{c}0.113 \\
\pm \\
0.01^{\mathrm{g}}\end{array}$ & $\begin{array}{c}0.276 \\
\pm \\
0.02^{\mathrm{e}}\end{array}$ \\
\hline $\begin{array}{l}\text { BWG } \\
\text { (g/ period) }\end{array}$ & $\begin{array}{c}42.27 \\
\pm \\
2.15^{\mathrm{a}}\end{array}$ & $\begin{array}{c}29.12 \\
\quad \pm \\
2.32^{\mathrm{a}}\end{array}$ & $\begin{array}{c}32.83 \\
\pm \\
7.31^{b}\end{array}$ & $\begin{array}{c}32.23 \\
\pm \\
7.31^{b}\end{array}$ & $\begin{array}{c}29.12 \\
\quad \pm \\
2.32^{\mathrm{a}}\end{array}$ & $\begin{array}{c}47.87 \\
\pm \\
7.57^{\mathrm{f}}\end{array}$ & $\begin{array}{c}41.92 \\
\pm \\
5.72^{f}\end{array}$ & $\begin{array}{c}41.49 \\
\pm \\
8.71^{\mathrm{f}}\end{array}$ & $\begin{array}{c}107.75 \\
\pm \\
5.26^{b}\end{array}$ \\
\hline
\end{tabular}


Effect of feeding sweet orange peels on blood glucose and lipid profile in Diabetic and hypercholesterolemic rats

Elsayed M Hammad; Magda R Kostandy and DoaaHEl-Sabakhawi

Data are expressed as mean $\pm S D$. Values within a row having different superscripts are significantly different $(p \leq 0.05)$;

Table (3): Effect of feeding different doses of orange peels on relative weight of the organs in diabetic and hypercholesterolemic rats

\begin{tabular}{|c|c|c|c|c|c|c|c|c|c|}
\hline $\begin{array}{l}\text { Groups } \\
\text { Parameter }\end{array}$ & $\begin{array}{c}\text { A } \\
(-\mathrm{ve} \\
)\end{array}$ & $\begin{array}{c}\text { B } \\
(+\mathrm{ve})\end{array}$ & $\begin{array}{l}\text { B1 } \\
5 \%\end{array}$ & $\begin{array}{c}\text { B2 } \\
7.5 \%\end{array}$ & $\begin{array}{c}\text { B3 } \\
10 \%\end{array}$ & $\begin{array}{c}\mathrm{C} \\
(+\mathrm{ve})\end{array}$ & $\begin{array}{l}\mathrm{C} 1 \\
5 \%\end{array}$ & $\begin{array}{c}\mathrm{C} 2 \\
7.5 \%\end{array}$ & $\begin{array}{c}\mathrm{C} 3 \\
10 \%\end{array}$ \\
\hline $\begin{array}{l}\text { Liver } \\
\text { relative } \\
\text { weight }\end{array}$ & $\begin{array}{c}3.15 \\
\pm \\
0.18^{\mathrm{g}}\end{array}$ & $\begin{array}{c}2.30 \\
\pm \\
0.01^{\mathrm{a}}\end{array}$ & $\begin{array}{c}2.43 \\
\pm \\
0.02^{\mathrm{a}}\end{array}$ & $\begin{array}{c}2.48 \\
\pm \\
0.03^{\mathrm{a}}\end{array}$ & $\begin{array}{c}2.53 \\
\pm \\
0.02^{\mathrm{b}}\end{array}$ & $\begin{array}{c}4.09 \\
\pm \\
0.06^{\mathrm{a}}\end{array}$ & $\begin{array}{c}3.89 \\
\pm \\
0.21^{\mathrm{b}}\end{array}$ & $\begin{array}{c}3.63 \\
\pm \\
0.19^{\mathrm{d}}\end{array}$ & $\begin{array}{c}3.89 \\
\pm \\
0.12^{b}\end{array}$ \\
\hline $\begin{array}{l}\text { Kidney } \\
\text { relative } \\
\text { weight }\end{array}$ & $\begin{array}{c}0.57 \\
\pm \\
0.01^{\mathrm{c}}\end{array}$ & $\begin{array}{c}1.28 \\
\pm \\
0.04^{\mathrm{a}}\end{array}$ & $\begin{array}{c}1.33 \\
\pm \\
0.02^{\mathrm{b}}\end{array}$ & $\begin{array}{c}1.40 \\
\pm \\
0.02^{\mathrm{b}}\end{array}$ & $\begin{array}{c}1.48 \\
\pm \\
0.01^{\mathrm{b}}\end{array}$ & $\begin{array}{c}0.64 \\
\pm \\
0.01^{\mathrm{a}}\end{array}$ & $\begin{array}{c}0.59 \\
\pm \\
0.22^{\mathrm{c}}\end{array}$ & $\begin{array}{c}0.58 \\
\pm \\
0.03^{\mathrm{c}}\end{array}$ & $\begin{array}{c}0.59 \\
\pm \\
0.03^{\mathrm{c}}\end{array}$ \\
\hline $\begin{array}{l}\text { Spleen } \\
\text { relative } \\
\text { weight }\end{array}$ & $\begin{array}{c}0.17 \\
\pm \\
0^{\mathrm{f}}\end{array}$ & $\begin{array}{c}0.41 \\
\pm \\
0.02^{\mathrm{a}}\end{array}$ & $\begin{array}{c}0.43 \\
\pm \\
0.01^{\mathrm{a}}\end{array}$ & $\begin{array}{c}0.46 \\
\pm \\
0.01^{\mathrm{a}}\end{array}$ & $\begin{array}{c}0.48 \\
\pm \\
0^{\mathrm{0.02}}\end{array}$ & $\begin{array}{c}0.27 \\
\pm \\
0^{\mathrm{a}} \mathbf{0 2}^{\mathrm{a}}\end{array}$ & $\begin{array}{c}0.20 \\
\pm \\
0.01^{\text {cd }}\end{array}$ & $\begin{array}{c}0.18 \\
\pm \\
0.01^{\mathrm{e}}\end{array}$ & $\begin{array}{c}0.19 \\
\pm \\
0^{\mathrm{dg}}\end{array}$ \\
\hline
\end{tabular}

Data are expressed as mean $\pm S D$. Values within a row having different superscripts are significantly different $(p \leq 0.05)$; 
Effect of feeding sweet orange peels on blood glucose and lipid profile in Diabetic and hypercholesterolemic rats

Table (4): Effect of feeding different doses of orange peels on glucose level in diabetic rats $(\mathrm{mg} / \mathrm{dl})$

\begin{tabular}{|lc|c|c|c|c|c|}
\hline Groups & & GA & GB & GB1 & GB2 & GB3 \\
Item & & & & & \\
\hline Blood & glucose & $\mathbf{8 9 . 8 0}$ & $\mathbf{3 8 8 . 2 0}$ & $\mathbf{2 8 8 . 3 0}$ & $\mathbf{2 5 7 . 7 0}$ & $\mathbf{2 1 8 . 5 0}$ \\
level & & \pm & \pm & \pm & \pm & \pm \\
& & $\mathbf{0 . 8 7}$ & $\mathbf{4 . 5 0}$ & $\mathbf{3 . 5 0}$ & $\mathbf{1 . 7 0}$ & $\mathbf{3 . 5 0}$ \\
& & f & $\mathbf{a}$ & $\mathbf{b}$ & $\mathbf{b}$ & $\mathbf{b}$ \\
\hline
\end{tabular}

Data are expressed as mean $\pm S D$. Values within a row having different superscripts are significantly different $(p \leq 0.05)$; 
Table (5): Effect of feeding different doses of orange peels on lipids profile in diabetic andhypercholesterolemic rats

\begin{tabular}{|c|c|c|c|c|c|c|c|c|c|}
\hline $\begin{array}{l}\text { Groups } \\
\text { Lipid profile }\end{array}$ & $\begin{array}{c}\text { A } \\
(-v e)\end{array}$ & $\begin{array}{c}\text { B } \\
(+v e)\end{array}$ & $\begin{array}{l}\text { B1 } \\
5 \%\end{array}$ & $\begin{array}{c}\text { B2 } \\
7.5 \%\end{array}$ & $\begin{array}{c}\text { B3 } \\
10 \%\end{array}$ & $\begin{array}{c}\text { C } \\
(+v e)\end{array}$ & $\begin{array}{l}\mathrm{C} 1 \\
5 \%\end{array}$ & $\begin{array}{c}\mathrm{C} 2 \\
7.5 \%\end{array}$ & $\begin{array}{c}\text { C3 } \\
10 \%\end{array}$ \\
\hline $\begin{array}{l}\text { Total } \\
\text { cholesterol } \\
(\mathrm{mg} / \mathrm{dl})\end{array}$ & $\begin{array}{c}78.39 \\
\pm \\
0.78^{\mathrm{e}}\end{array}$ & $\begin{array}{c}120.9 \\
\pm \\
0.78^{\mathrm{a}}\end{array}$ & $\begin{array}{c}111.54 \\
\pm \\
0.39^{\mathrm{b}}\end{array}$ & $\begin{array}{c}103.35 \\
\pm \\
1.17^{\mathrm{a}}\end{array}$ & $\begin{array}{c}93.99 \\
\pm \\
0.78^{d}\end{array}$ & $\begin{array}{c}206.55 \\
\pm \\
12.38^{\mathrm{a}}\end{array}$ & $\begin{array}{c}121.29 \\
\pm \\
6.92^{\mathrm{h}}\end{array}$ & $\begin{array}{c}115.12 \\
\pm \\
4.71^{\mathrm{i}}\end{array}$ & $\begin{array}{c}140.78 \\
\pm \\
1.72^{d}\end{array}$ \\
\hline $\begin{array}{l}\text { Triglycerides } \\
\text { (mg/dl) }\end{array}$ & $\begin{array}{c}97.68 \\
\pm \\
1.76^{c}\end{array}$ & $\begin{array}{c}142.56 \\
\pm \\
2.64^{\mathrm{a}}\end{array}$ & $\begin{array}{c}124.96 \\
\pm \\
\text { 0.88 }^{b}\end{array}$ & $\begin{array}{c}122.32 \\
\pm \\
0.88^{b}\end{array}$ & $\begin{array}{c}107.3 \\
\pm \\
1.76\end{array}$ & $\begin{array}{c}120.70 \\
\pm \\
3.11^{\mathrm{a}}\end{array}$ & $\begin{array}{c}53.40 \\
\pm \\
2.04^{f}\end{array}$ & $\begin{array}{c}44.30 \\
\pm \\
1.44^{\text {gh }}\end{array}$ & $\begin{array}{r}80.00 \pm \\
3.82^{b}\end{array}$ \\
\hline
\end{tabular}

Data are expressed as mean $\pm S D$. Values within a row having different superscripts are significantly different $(p \leq 0.05)$; 
Table (6): Effect of feeding different doses of orange peels on liver functions in diabeticand hypercholesterolemic rats

\begin{tabular}{|c|c|c|c|c|c|c|c|c|c|}
\hline $\begin{array}{l}\text { Groups } \\
\text { Liver enzymes }\end{array}$ & $\begin{array}{l}\text { A } \\
(-v e)\end{array}$ & $\begin{array}{l}\text { B } \\
(+v e)\end{array}$ & $\begin{array}{l}\text { B1 } \\
5 \%\end{array}$ & $\begin{array}{l}\text { B2 } \\
7.5 \%\end{array}$ & $\begin{array}{l}33 \\
10 \%\end{array}$ & $\begin{array}{l}\text { C } \\
(+v e)\end{array}$ & $\begin{array}{l}\mathrm{C1} \\
5 \%\end{array}$ & $\begin{array}{l}\mathrm{C} 2 \\
7.5 \%\end{array}$ & $\begin{array}{l}\text { C3 } \\
10 \%\end{array}$ \\
\hline $\operatorname{AST}(\mathrm{U} / \mathrm{L})$ & $\begin{array}{l}18.06 \\
\pm \\
1.07^{\mathrm{f}}\end{array}$ & $\begin{array}{l}32.10 \pm \\
0.10^{\mathrm{a}}\end{array}$ & $\begin{array}{l}30.10 \pm \\
0.10^{\mathrm{a}}\end{array}$ & $\begin{array}{l}27.10 \\
\pm \\
0.11^{b}\end{array}$ & $\begin{array}{l}24.10 \pm \\
0.35^{\mathrm{b}}\end{array}$ & $\begin{array}{l}37.25 \\
\pm \\
5.82^{\mathrm{a}}\end{array}$ & $\begin{array}{l}28.66 \\
\pm \\
1.76^{b}\end{array}$ & $\begin{array}{l}24.87 \\
\pm \\
0.42^{d}\end{array}$ & $\begin{array}{l}22.31 \\
\pm \\
1.80^{e}\end{array}$ \\
\hline $\mathbf{A L T}(\mathbf{U} / \mathbf{L})$ & $\begin{array}{l}9.51 \\
\pm \\
0.94^{h}\end{array}$ & $\begin{array}{l}29.40 \pm \\
2.50^{\mathrm{a}}\end{array}$ & $\begin{array}{l}26.40 \pm \\
2.01^{b}\end{array}$ & $\begin{array}{l}24.80 \\
\pm \\
2.20^{b}\end{array}$ & $\begin{array}{l}22.10 \\
\pm \\
2.10^{c}\end{array}$ & $\begin{array}{l}16.10 \\
\pm \\
1.10^{a}\end{array}$ & $\begin{array}{l}11.29 \\
\pm \\
0.26^{\text {ef }}\end{array}$ & $\begin{array}{l}11.79 \\
\pm \\
2.28^{f}\end{array}$ & $\begin{array}{l}10.44 \\
\pm \\
0.79^{g}\end{array}$ \\
\hline
\end{tabular}

Data are expressed as mean $\pm S D$. Values within a row having different superscripts are significantly different $(p \leq 0.05)$; 
Table (7): Effect of feeding different doses of orange peels on kidney functions in diabetic and hypercholesterolemicrats

\begin{tabular}{|c|c|c|c|c|c|c|c|c|c|}
\hline $\begin{array}{l}\text { Groups } \\
\text { kidney function }\end{array}$ & $\begin{array}{l}\text { A } \\
\text { (-ve ) }\end{array}$ & $\begin{array}{l}\text { B } \\
(+v e)\end{array}$ & $\begin{array}{l}\text { B1 } \\
5 \%\end{array}$ & $\begin{array}{l}\text { B2 } \\
7.5 \%\end{array}$ & $\begin{array}{l}\text { B3 } \\
10 \%\end{array}$ & $\begin{array}{l}\text { C } \\
(+v e)\end{array}$ & $\begin{array}{l}\mathrm{C} 1 \\
5 \%\end{array}$ & $\begin{array}{l}\text { C2 } \\
7.5 \%\end{array}$ & $\begin{array}{l}\text { C3 } \\
10 \%\end{array}$ \\
\hline $\begin{array}{l}\text { Creatinine } \\
(\mathrm{mg} / \mathrm{dl})\end{array}$ & $\begin{array}{l}0.69 \\
\pm \\
0.31^{\mathrm{g}}\end{array}$ & $\begin{array}{l}0.74 \\
\pm \\
0.10^{\mathrm{a}}\end{array}$ & $\begin{array}{ll}0.70 \quad \pm \\
0.20^{\mathrm{b}}\end{array}$ & $\begin{array}{ll}0.66 & \pm \\
0.20^{\mathrm{b}} & \end{array}$ & $\begin{array}{l}0.63 \\
\pm \\
0.20^{b}\end{array}$ & $\begin{array}{l}1.88 \\
\pm \\
0.12^{\mathrm{a}}\end{array}$ & $\begin{array}{l}1.74 \\
\pm \\
0.09^{b}\end{array}$ & $\begin{array}{l}1.53 \\
\pm \\
0.11^{\mathrm{c}}\end{array}$ & $\begin{array}{l}1.42 \\
\pm \\
0.05^{d f}\end{array}$ \\
\hline $\begin{array}{l}\text { Urea } \\
(\mathrm{mg} / \mathrm{dl})\end{array}$ & $\begin{array}{l}14.70 \pm \\
0.90^{h}\end{array}$ & $\begin{array}{l}26.60 \pm \\
2.20^{a}\end{array}$ & $\begin{array}{l}20.60 \pm \\
1.40^{\text {cd }}\end{array}$ & $\begin{array}{l}20.90 \pm \\
0.60^{c}\end{array}$ & $\begin{array}{l}22.60 \\
\pm \\
1.90^{b}\end{array}$ & $\begin{array}{l}47.35 \\
\pm \\
0.10^{a}\end{array}$ & $\begin{array}{l}44.15 \\
\pm \\
0.20^{a}\end{array}$ & $\begin{array}{l}42.10 \\
\pm \\
0.30^{b}\end{array}$ & $\begin{array}{l}38.00 \pm \\
0.02^{b}\end{array}$ \\
\hline
\end{tabular}

Data are expressed as mean $\pm S D$. Values within a row having different superscripts are significantly different $(p \leq 0.05)$ 


\section{تأثّير استخدام قشّر البرثمّال على مستوى سكر ود هون

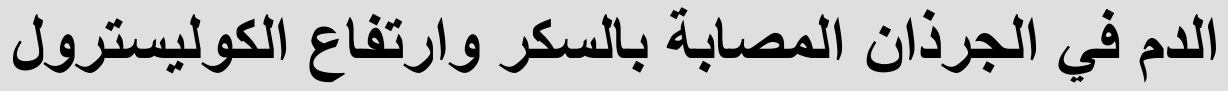

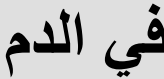 \\ السيد محمود حماد و ماجدة رمزي قسطندي و دعاء حامد السبخاوي \\ المعهد القومي للتغذية الملخص العربي}

بعتبر البرتقال من الفواكه المنتشرة والمعروفة في مصر والمتناولة بكميات كبيرة و نظرا

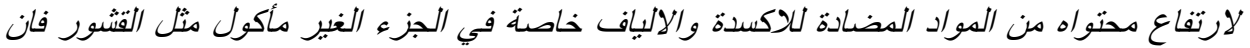

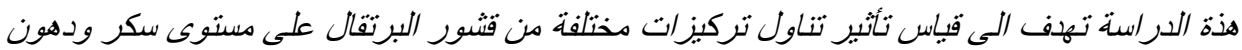

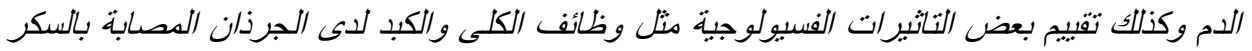

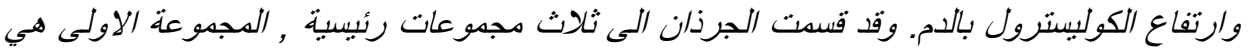

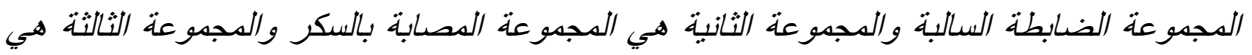

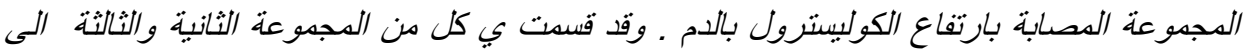

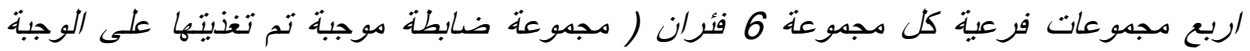

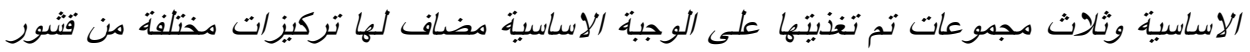

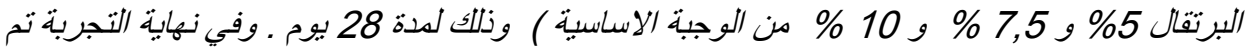
حساب معدل اكتساب الوزن ومعدل كفاءةالطعام ـ كما تم جهع عينات الدم لقياس مستوى سكر الدما

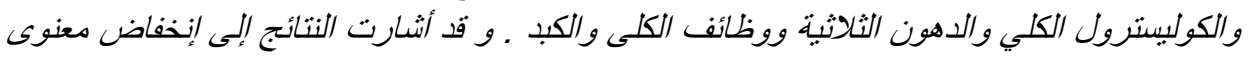

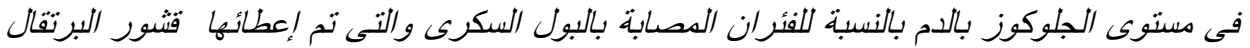

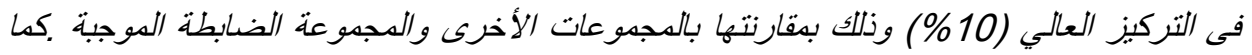

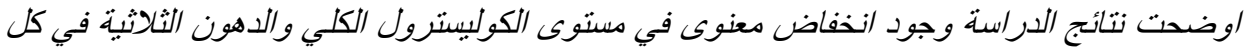

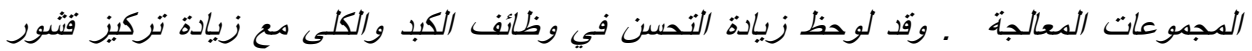

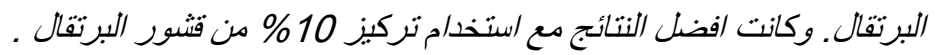

الكلمات الدالة : قشور البرتقال , مستوى سكر الدم , وظائف الكبد و الكلى , صورة الدهون 